\title{
Performance Evaluation of Ceramic Filters for Raw Water Treatment
}

\author{
Fahriza Fawwas Asrory $^{1 *}$, Agus Prasetya ${ }^{2}$, Wahyu Wilopo ${ }^{1,2}$ \\ ${ }^{1}$ Masters in System Engineering, Faculty of Engineering, Universitas Gadjah Mada, Jl. Teknika Utara no. 3 Barek, \\ Yogyakarta 55281, Indonesia \\ ${ }^{2}$ Department of Chemical Engineering, Faculty of Engineering, Universitas Gadjah Mada, Jl. Grafika no. 2 Kampus \\ UGM, Yogyakarta 55281, Indonesia \\ ${ }^{3}$ Department of Geological Engineering, Faculty of Engineering, Universitas Gadjah Mada, Jl. Grafika no. 2 Kampus \\ UGM , Yogyakarta 55281, Indonesia
}

( Received: August 26, 2019, Revised: February 28, 2020, Accepted: September 2, 2020 )

\begin{abstract}
The drought that engulfs Gunungkidul every year forces some residents to use surface water resources in the lake or water sources in the cave even though the quality has not been tested. The application of ceramic filter technology as a household-scale water purification tool is a form of preventing further water contamination and reduces the level of the disease occurs due to the influence of biological and chemical contamination contained in water. This study aims to make ceramic filters and evaluate the performance of these filters by testing four parameters namely turbidity, hardness, E.coli, and Total Coliform. This study uses three filters, namely Pelita Indonesia (F1) production filter as a comparison filter, Kasongan Yogyakarta production filter with a composition of $80 \%$ (clay and sand) with a ratio of 1:1 and $20 \%$ wood sawdust with the addition of Silver Nitrate $\left(\mathrm{AgNO}_{3}\right)$ ( F2), and Kasongan production filter with a composition of $100 \%$ clay mixed with sand without the addition of sawdust and Silver Nitrate $\left(\mathrm{AgNO}_{3}\right)$ (F3). Sampling was carried out 15 times for 15 days by testing the water before and after going through the filtration process. The percentage reduction in the average for the turbidity parameter, (F1) was $38.24 \%$, (F2) was $34.16 \%$, and (F3) was $37.18 \%$. The hardness parameter, $(\mathrm{F} 1)$ is $22.22 \%$, (F2) is $11.24 \%$, and $(\mathrm{F} 3)$ is $10.93 \%$. The parameters of E.coli, (F1) are 100\%, (F2) are $98.66 \%$, and the filter with the composition of clay, sand (F3) is $46.71 \%$. The Total Coliform (F1) parameter was $87.62 \%$, (F2) was $69.38 \%$, and (F3) was $51.32 \%$. The application of ceramic filters can be done by looking at the ability of the filter to reduce the contamination contained in water. The addition of silver nitrate $\left(\mathrm{AgNO}_{3}\right)$ must be done to reduce microbiological contamination.
\end{abstract}

Keywords: Ceramic filters, Turbidity, Hardness, Total Coliform, and E.coli.

\section{INTRODUCTION}

Gunungkidul Regency is one of the regencies in Indonesia where most of the administrative area is covered by karst. This regency is located in the Batur mountainous region, Basin Wonosari, and the Gunungsewu Karst Mountains. Gunungkidul Regency is attached to the problem of drought. Data from the Gunungkidul Regional Disaster Management Agency (BPBD) recorded that in 2018 drought-hit 14 sub-districts out of a total of 18 subdistricts in Gunungkidul. Residents affected by the drought reached 122.104 people. Lack of clean

\footnotetext{
* Corresponding author.

E-mail address: riza.asrory@gmail.com
}

water assistance to residents, forcing some residents to use surface water resources in the lake or water sources in the cave despite the quality untested.

The main problem faced by water resources at the moment is water quality that is declining. Data from the Ministry of Health in 2014 recorded that in 2013 cases of diarrhea in Indonesia reached $5,078,830$ cases. This is caused by water quality and poor regulation of water supply [10]. WHO recommends water purification systems at the household scale as a form of preventing further water contamination and reducing the rate of diarrhea. Research conducted by Fewtrell et al. [4], Hutton and Haller [6] and Clasen et al. [2], states that the water purification process at the household 
scale provides a higher level of effectiveness compared to the central water purification process.

One of the technologies used in the water purification process is a membrane. These technological advantages include, membrane technology requires lower energy in operation and maintenance, besides the design and construction of membranes can be used on small scale systems. One of the materials used in making membranes is ceramics. The water purification process using ceramic filters is the most effective purification system compared to other purification systems at the household scale [2]. Ceramic filters have been widely produced and used in the world, one of which is Ceramic Pot Filters (CPF). Ceramic Pot Filters (CPF) has been widely used in various countries as an effective water treatment system.

Safe and healthy water for consumption must meet several criteria such as clear, colorless, odorless, tasteless, free from infecting microorganisms and free of harmful chemicals [1].
In a previous study, Matthies [9] developed a local ceramic filter for point of use water treatment in the Gunungkidul Regency. The filter production process involves local ceramic craftsmen precisely in the Kasongan Bantul Special Region of Yogyakarta with available local materials. However, the ceramic filter has not yet passed the direct testing stage in Gunungkidul. This research will test the performance of ceramic filters from previous studies and ceramic filters Kasongan local production and existing filters, namely ceramic filters produced by the Indonesian Pelita Association as a comparison filter.

\section{EXPERIMENTAL METHOD}

The clays used in this study came from the Mangunan and Kulonprogo regions. The mixing material is in the form of sand originating from the Kulonprogo area and used as a mixture to strengthen the structure of the ceramic filter so that it does not break easily during the combustion process. In this study, the independent variables used are 3 variations of earthenware filters.

Table 1. Filter Characteristics Table

\begin{tabular}{|c|c|c|c|c|c|c|c|}
\hline \multirow[b]{2}{*}{ Filter Type } & \multicolumn{3}{|c|}{ Dimension } & \multirow[b]{2}{*}{$\begin{array}{l}\text { Thickne } \\
\text { ss (cm) }\end{array}$} & \multirow[b]{2}{*}{ Composition } & \multirow[b]{2}{*}{$\begin{array}{c}\text { Capacity } \\
\text { (liter) }\end{array}$} & \multirow[b]{2}{*}{$\begin{array}{c}\text { Weight } \\
(\mathbf{k g})\end{array}$} \\
\hline & $\begin{array}{l}\text { High } \\
(\mathrm{cm})\end{array}$ & $\begin{array}{c}\text { Top } \\
\text { Diameter } \\
(\mathbf{c m})\end{array}$ & $\begin{array}{l}\text { Bottom } \\
\text { Diameter } \\
(\mathbf{c m})\end{array}$ & & & & \\
\hline Filter $1(\mathrm{~F} 1)$ & 21 & 30 & 17 & 1,5 & - & 7,6 & 3 \\
\hline Filter $2(\mathrm{~F} 2)$ & 21 & 30 & 17 & 1,5 & $\begin{array}{l}\text { Clay, sand, } \\
\text { sawdust, } \\
\mathrm{AgNO}_{3}\end{array}$ & 7,6 & 3 \\
\hline Filter $3(\mathrm{~F} 3)$ & 21 & 30 & 17 & 1,5 & Clay, sand & 7,6 & 3 \\
\hline
\end{tabular}

Table 2. Water Biological Chemical Parameters for Research

\begin{tabular}{cccc}
\hline No & Parameter & Unit & Maximum Allowable Level \\
\hline 1 & Turbidity* & NTU & 5 \\
2 & Hardness* & $\mathrm{mg} / 1$ & 500 \\
3 & E.coli** & CFU/100ml & 0 \\
4 & Total Coliform ** & CFU/100ml & 0 \\
\hline$*$ Mandatory parameters that are directly related to health \\
$* *$ Mandatory parameters that are not directly related to health
\end{tabular}


F1 or first filter is a comparison filter produced by the Bandung Pelita Indonesia Foundation and already used by several residents in Pucanganom.

F2 or the second filter is the Kasongan production filter Yogyakarta, which is a center for ceramics production in the Special Region of Yogyakarta. This filter uses a clay composition from the Yogyakarta region with a composition of $80 \%$ (clay and sand) with a ratio of 1:1 and 20\% wood sawdust with the addition of Silver Nitrate $\left(\mathrm{AgNO}_{3}\right)$.

F3 or the third filter is the Kasongan production filter with a composition of $100 \%$ clay mixed with sand without the addition of sawdust and Silver Nitrate $\left(\mathrm{AgNO}_{3}\right)$.

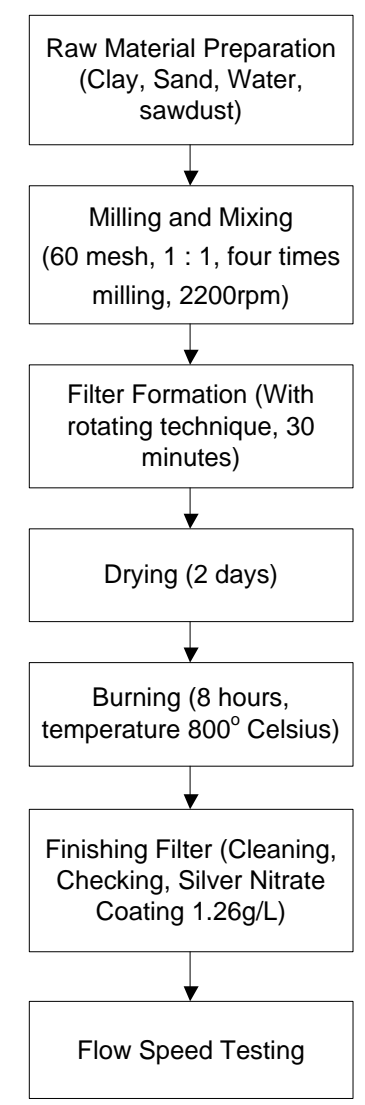

Figure 1. Filter Making Process

Sampling was carried out 15 times for 15 days. The water sample used came from a community well in Pucanganom Village, Rongkop District, Gunungkidul Regency. Filtration of water from the sampling takes place after 24 hours from the time of filling. The sample is then put into a bottle different for chemical parameters (hardness and turbidity) and biological parameters (Total Coliform and E.coli). The number of samples taken for each parameter is $500 \mathrm{ml}$.

Water sample testing is carried out in the BBTKLPP lab (Balai Great Environmental Health
Engineering and Control Disease) Yogyakarta Jl. Wiyoro Lor, Bumiwetan, Baturetno, Banguntapan, Bantul, Special Region Yogyakarta.

The hardness test uses SNI 06-6989.25-2005. The turbidity test uses the SNI test method 066989.12-2004. E. coli and Total Coliform Test using the APHA 2012 Section $9222 \mathrm{H}$ test method and APHA 2012 Section $9222 \mathrm{H}$.

Data processing is based on retrieval sample at the research site and test results laboratory of the parameters, i.e. hardness, turbidity, total coliform, and E.coli so primary data obtained. Tests are carried out on the water before and after the filtration process. Laboratory test results will then be analyzed and graphs using EXCEL software, comparing the parameters of water treatment results with quality standards for drinking water standards based on the Republic of Indonesia's Minister of Health Regulation No. 492 of 2010. Data that has been obtained from the test results will then be analyzed, discussed and concluded.

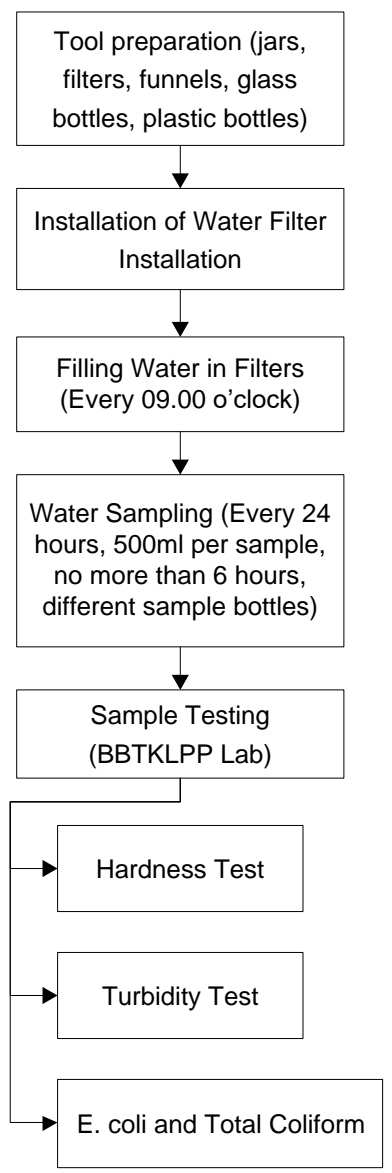

Figure 2. Evaluation of Filter Performance

\section{RESULTS AND DISCUSSION}

Data from the hardness and turbidity test results that have been performed are presented in Table 3. 
Table 3. Hardness and Turbidity Test Results

\begin{tabular}{ccccccccc}
\hline \multirow{3}{*}{ Day } & \multicolumn{3}{c}{ Hardness $(\mathbf{m g} / \mathbf{L})$} & \multicolumn{5}{c}{ Turbidity (NTU) } \\
\cline { 2 - 9 } & TP & F1 & F2 & F3 & TP & F1 & F2 & F3 \\
\hline 1 & 148 & 136 & 141 & 140 & 0.5 & 0.3 & 0.4 & 0.3 \\
2 & 152 & 130 & 148 & 138 & 0.6 & 0.5 & 0.5 & 0.8 \\
3 & 144.72 & 126.63 & 144.72 & 136.68 & 0.3 & 0.4 & 0.3 & 0.5 \\
4 & 134 & 134 & 160 & 150 & 1.2 & 1.2 & 1 & 1.2 \\
5 & 159.6 & 131.31 & 155.55 & 155.55 & 0.8 & 0.7 & 1 & 0.7 \\
6 & 149.25 & 127.36 & 151.24 & 147.26 & 0.7 & 0.5 & 0.5 & 0.5 \\
7 & 120 & 126 & 146.73 & 148.74 & 1.2 & 0.7 & 0.5 & 1.1 \\
8 & 206.96 & 123.38 & 145.27 & 149.25 & 0.5 & 0.4 & 0.4 & 0.6 \\
9 & 173.13 & 117.41 & 139.3 & 147.26 & 0.6 & 0.5 & 0.4 & 0.4 \\
10 & 137.03 & 240.77 & 169.15 & 164.82 & 1.5 & 1.8 & 1.6 & 2.1 \\
11 & 192 & 116 & 176 & 138 & 1.7 & 0.6 & 0.6 & 0.6 \\
12 & 158.42 & 118.81 & 132.67 & 134.65 & 0.7 & 0.5 & 0.7 & 1.3 \\
13 & 186.14 & 134.67 & 174.87 & 172.86 & 1 & 0.3 & 0.7 & 0.4 \\
14 & 168.84 & 132.66 & 170.85 & 154.77 & 1.6 & 0.3 & 0.6 & 0.8 \\
15 & 154.77 & 134.67 & 176.88 & 146 & 0.4 & 0.4 & 0.3 & 0.4 \\
\hline
\end{tabular}

Information :

CFU : Colony Forming

TNTC : Too Numerous to Count

Units TNTC

NTU
: $>200$

: Nephelometric Turbiditi Unit

TP (Tap Water)

Filter $1(\mathrm{~F} 1)$ : Comparative filter production from Pelita Indonesia

Filter 2 (F2) : Composition $80 \%$ clay and sand $+20 \%$ sawdust $+\mathrm{AgNO}_{3}$

Filter 2 (F2): Composition $80 \%$ clay and sand $+20 \%$ sawdust $+\mathrm{AgNO}_{3}$

Table 4. Percentage of Average Decrease

\begin{tabular}{cccccc}
\hline & Turbidity & \multicolumn{3}{c}{ Hardness } \\
\hline F1 & F2 & F3 & F1 & F2 & F3 \\
\hline 38.24 & 34.16 & 37.18 & 22.22 & 11.24 & 10.93 \\
\hline
\end{tabular}

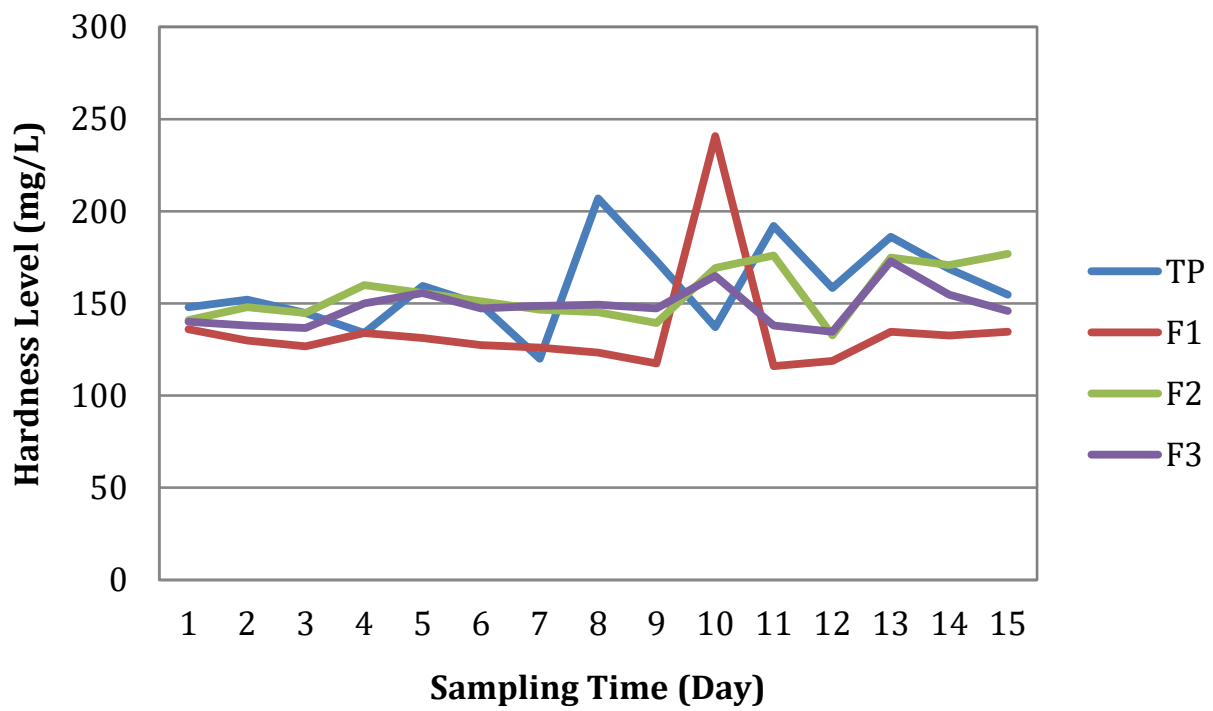

Figure 3. Hardness level 


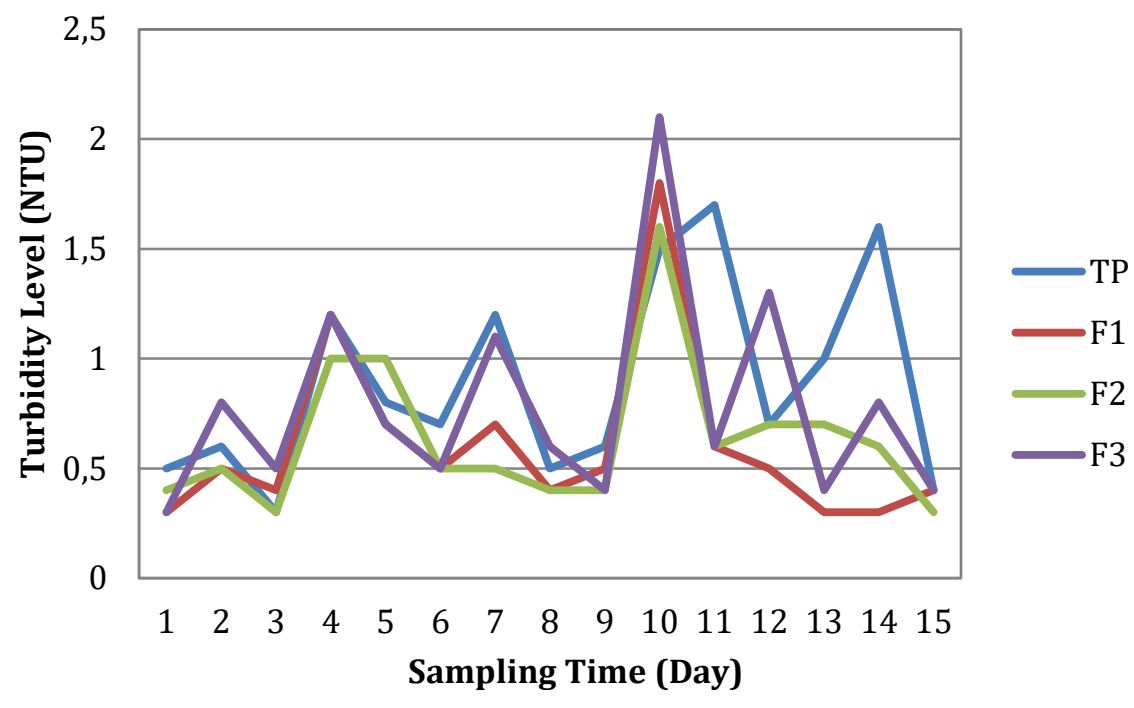

Figure 4. Turbidity Level

In Figure 3, it can be seen the difference in the level of hardness between TP (Tap Water) and water from filtration using filters F1, F2, and F3. Hardness level on TP (Tap Water) of 15 times the test is still below the $500 \mathrm{mg} / \mathrm{L}$ number which is still below the maximum permissible level of drinking water quality requirements by following the Regulation of the Minister of Health of the Republic of Indonesia number 492 of 2010. It can be concluded that the water conditions in the Pucanganom area are still quite good. F1 filter can reduce the level of hardness, but the ability of the filter in reducing hardness is unstable. The percentage decrease in hardness is relatively small with an average percentage value of F1 22.22\%, F2 $11.24 \%$, and F3 $10.93 \%$.

In Figure 4 we can see the difference in turbidity level between TP (Tap Water) and water from filtration using filters F1, F2, and F3. The turbidity level in TP (Tap Water) from 15 times of testing is still under 5 NTU where the number is still below the maximum allowed level as a condition for drinking water quality according to the Regulation of the Minister of Health of the Republic of Indonesia number 492 of 2010. It can be concluded that the water conditions in the Pucanganom area are still quite good. F1 filter can reduce the turbidity level, but the ability of the filter in reducing turbidity is not stable. The percentage of turbidity reduction is relatively small with an average percentage value of $\mathrm{F} 138.24 \%$, F2 $34.16 \%$, and F3 $37.18 \%$

The filtration process that is carried out continuously makes the filter reach its saturation point to make the filter fail to do the filtration process. The filtration process is carried out continuously causing sedimentation in the filter. The process of cleaning and regular maintenance of the filter needs to be done [13] to reduce the sedimentation that occurs in the filter so that the failure of the filtration process can be minimized. The filtration process using ceramic pot filters has considerable variation in yield [13]. The filter production process that still uses manual or handmade processes makes the variation of filtration results quite large [12]. The combustion process also plays an important role in filter quality. The right combustion temperature and the right process time can produce a perfectly cooked filter. Filters that are less complete at the combustion stage, make the filter structure less than perfect. An imperfect filter if used in the filtration process continuously will cause the decay of filter particles which will eventually settle inside the filter. Sediment this will affect the filter's ability to reduce turbidity in water. The filter will soften longer so that the structure becomes weak and eventually breaks.

Data from the Total Coliform and E.coli test results that have been performed are presented in Table 5.

In Figure 5 we can see the difference in Total Coliform between TP (Tap Water) and filtration water using F1, F2, and F3 filters. Level of Total Coliform on TP (Tap Water) from 15 times of testing quite high even there are 11 times the total Coliform content expressed TNTC (Too Numerous to Count) which means the total Coliform in water exceeds $200 \mathrm{CFU} / 100 \mathrm{~mL}$. This number has exceeded the maximum allowable limit of $0 \mathrm{CFU} /$ $100 \mathrm{~mL}$ as a requirement for drinking water quality according to the Regulation of the Minister of 
Table 5. Total Coliform and E.coli Test Results

\begin{tabular}{ccccccccc}
\hline \multirow{2}{*}{ Hari } & \multicolumn{4}{c}{ Total Coliform $($ CFU/100ml) } & \multicolumn{5}{c}{ E. coli (CFU/100ml) } \\
\cline { 2 - 8 } & TP & F1 & F2 & F3 & TP & F1 & F2 & F3 \\
\hline 1 & TNTC & 95 & 0 & TNTC & 1 & 0 & 0 & 10 \\
2 & 139 & 3 & 77 & TNTC & 0 & 0 & 0 & 0 \\
3 & TNTC & 11 & 150 & TNTC & 2 & 0 & 0 & 0 \\
4 & TNTC & 127 & 23 & TNTC & 0 & 0 & 0 & 0 \\
5 & TNTC & 28 & 165 & 38 & 2 & 0 & 0 & 2 \\
6 & TNTC & 85 & 0 & 157 & 8 & 0 & 0 & 3 \\
7 & TNTC & 6 & 3 & 20 & 37 & 0 & 0 & 15 \\
8 & TNTC & 0 & 4 & TNTC & 133 & 0 & 1 & 188 \\
9 & TNTC & 0 & 182 & TNTC & 118 & 0 & 0 & 77 \\
10 & TNTC & 0 & 60 & TNTC & TNTC & 0 & 0 & 148 \\
11 & TNTC & 12 & 57 & TNTC & 26 & 0 & 4 & 18 \\
12 & 154 & 0 & 26 & 163 & 37 & 0 & 0 & 32 \\
13 & 63 & 0 & 41 & 137 & 23 & 0 & 0 & 51 \\
14 & TNTC & 1 & 0 & 76 & 0 & 0 & 0 & 21 \\
15 & 96 & 1 & 0 & 94 & 26 & 0 & 0 & 27 \\
\hline
\end{tabular}

Information :

CFU : Colony Forming

TNTC : Too Numerous to Count

Units TNTC

NTU
: $>200$

: Nephelometric Turbiditi Unit

TP (Tap Water)

Filter 1 (F1) : Comparative filter production from Pelita Indonesia

Filter 2 (F2) : Composition $80 \%$ clay and sand $+20 \%$ sawdust $+\mathrm{AgNO}_{3}$

Filter 2 (F2) : Composition $80 \%$ clay and sand $+20 \%$ sawdust $+\mathrm{AgNO}_{3}$

Table 6. Percentage of Average Decrease

\begin{tabular}{cccccc}
\hline & E.coli & \multicolumn{4}{c}{ Total Coliform } \\
\hline F1 & F2 & F3 & F1 & F2 & F3 \\
\hline 100 & 98.66 & 46.71 & 87.62 & 69.38 & 51.32 \\
\hline
\end{tabular}

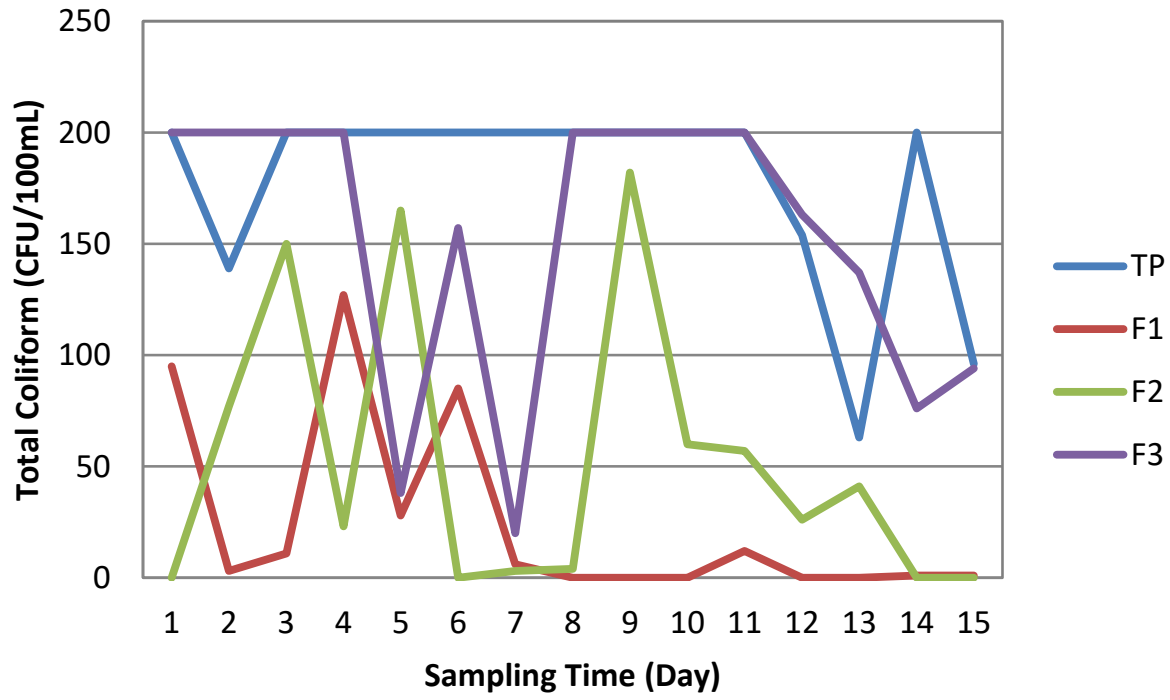

Figure 5. Total Coliform 


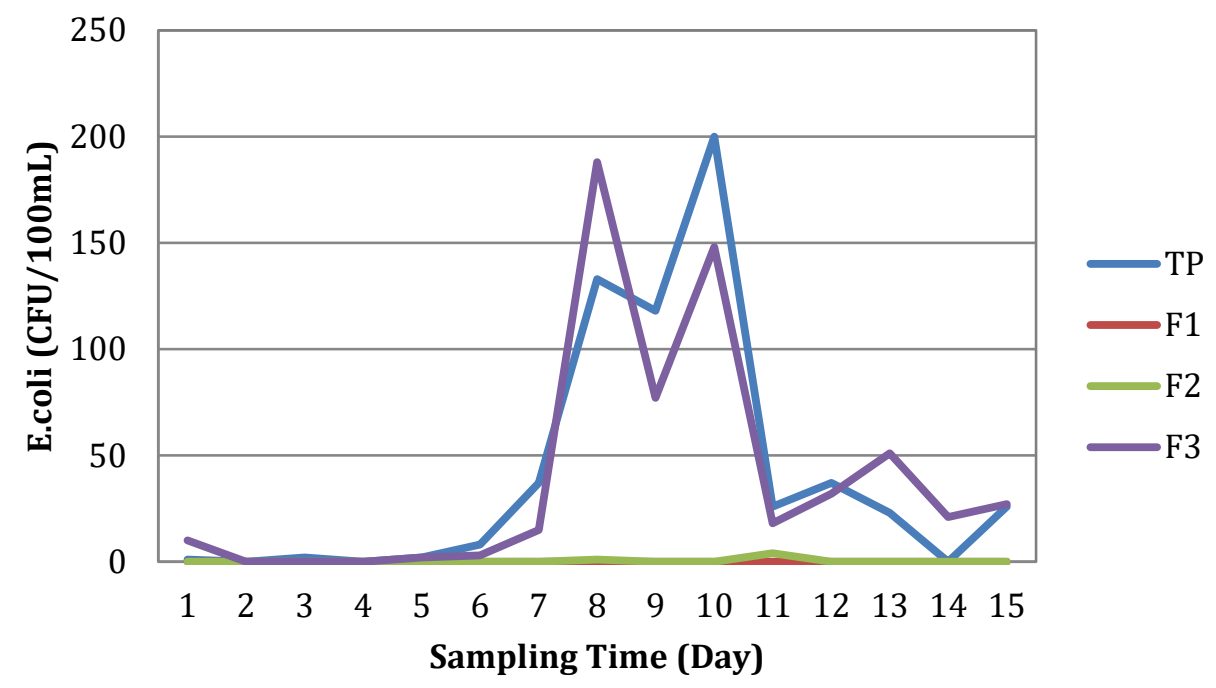

Figure 6. E.coli

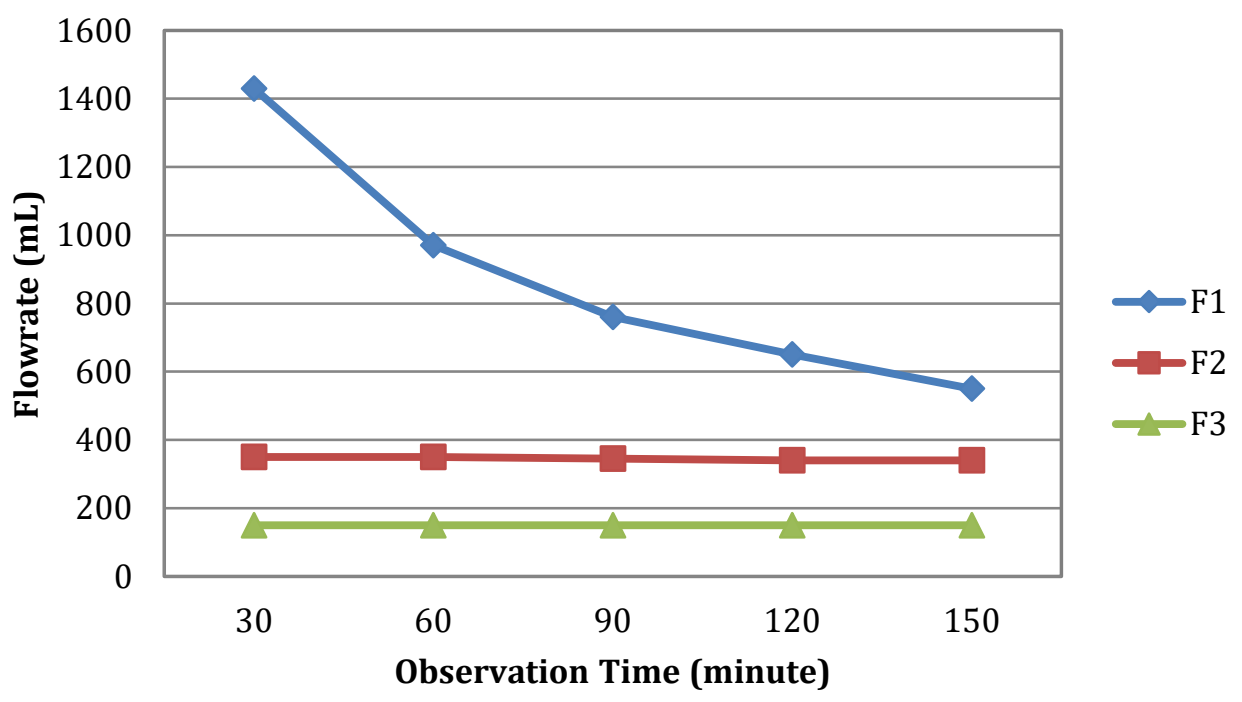

Figure 7. Flowrate F1, F2, dan F3

Health of the Republic of Indonesia number 492 of 2010. Filters F1, F2, and F3 can reduce Total Coliform in water even though it is not perfect. Table 5 can be seen as the percentage of total decline Coliform on F1, F2, and F3 filters from day 1 to day 15 with an average percentage decrease in Total Coliform of $87.62 \%, 69.38 \%$, and $51.32 \%$. Although the F1 and F2 filters can reduce the Total Coliform in water, judging by the number of Total Coliform in water the filtration results can be concluded that water is not feasible if consumed directly. By following the Regulation of the Minister of Health of the Republic of Indonesia number 492 of 2010 the maximum permissible level is $0 \mathrm{CFU} / 100 \mathrm{~mL}$.

Figure 6 can be seen as the difference in levels of E.coli between TP (Tap Water) with water filtration using filters F1, F2, and F3. E. coli levels in TP (Tap Water) from 15 times of testing are quite high an increase in E. coli levels on the 7th day to the 13th day. This figure has exceeded the maximum allowable limit of $0 \mathrm{CFU} / 100 \mathrm{~mL}$ as a requirement for drinking water quality according to the Regulations Minister of Health of the Republic of Indonesia number 492 of 2010. Table 5 can be seen as the percentage of reduction in Ecoli on F1, $\mathrm{F} 2$, and F3 filters from day 1 to day 15 with an average percentage of E.coli decreased by $100 \%$, $98.66 \%$, and $46.71 \%$.

The addition of silver nitrate $\left(\mathrm{AgNO}_{3}\right)$ to the filter has a big effect on the reduction of E.coli in water. The absence of the addition of silver nitrate to the $\mathrm{F} 3\left(\mathrm{AgNO}_{3}\right)$ filter causes the filter's ability to reduce levels of E.coli in water not so good. To the ceramic filter, the silver liquid is usually added to reduce bacterial levels such as Total Coliform and E.coli [5]. Pottery filters that do not use silver additives are less effective in reducing levels of 
E.coli [11]. Sampling is done every 24 hours. This results in prolonged contact between the water stored in the filter and the silver nitrate $\left(\mathrm{AgNO}_{3}\right)$ content in the ceramic filter. In the case of Ceramic Pot Filters, Van Der Laan et al. [12] explain that the main mechanism in bacterial reduction is the residence time of water in the filter which allows longer contact between silver nitrate $\left(\mathrm{AgNO}_{3}\right)$ and filtrated water. Research conducted by Van Der Laan et al. [12] shows that residence time is the most dominant parameter in the process of decreasing bacterial content during the filtration process, not the contact between silver nitrate $\left(\mathrm{AgNO}_{3}\right)$ and filtrated water.

The flow rate of water decreases more and more because of the volume of water that is contained in the filter decreases. On filters F2 and $\mathrm{F} 3$, the water flow velocity is quite stable, but the volume of water is dripping quite small. The addition of sawdust on the F2 filter makes the flow rate of water in the $\mathrm{F} 1$ filter greater than the $\mathrm{F} 2$ filter were in the F2 filter no addition of sawdust in the process the making of it. The increase in water flow rate increases with the amount of sawdust mixed with ceramic filters [3]. The process of making ceramic filters manually by going through the surface refinement process causes the water flow rate is not so large because the pores outside the ceramic filter are closed.

\section{CONCLUSION}

There are differences in turbidity levels, hardness levels, levels of E. coli and Total Coliform before and after passing the ceramic filter. Percentage reduction in average for turbidity parameters, ceramic filters produced by Pelita Indonesia Foundation (F1) was $38.24 \%$, ceramic filters with clay, sand, wood powder, $\mathrm{AgNO}_{3}$ (F2) composition by $34.16 \%$, and filters with clay composition sand (F3) by 37.18\%. Percentage reduction in average for hardness parameters, ceramic filters produced by the Pelita Indonesia Foundation (F1) $22.22 \%$, ceramic filters with a composition of clay, sand, sawdust, $\mathrm{AgNO}_{3}$ (F2) of $11.24 \%$, and filters with a composition of clay, sand (F3) of $10.93 \%$. The average reduction percentage for E.coli parameters, ceramic filters produced by the Pelita Indonesia Foundation (F1) by 100\%, ceramic filters with the composition of clay, sand, sawdust, $\mathrm{AgNO}_{3}(\mathrm{~F} 2)$ by $98.66 \%$, and filters with the composition of clay, sand (F3) of $46.71 \%$. Average percentage reduction for the Total parameter Coliform, ceramic filters produced by Pelita Indonesia Foundation (F1) by $87.62 \%$, ceramic filters with clay, sand, wood powder,
$\mathrm{AgNO}_{3}$ (F2) composition at $69.38 \%$, and filters with clay, sand (F3) composition by $51,32 \%$.

Judging from the ability of filters to reduce biological and chemical contamination in water, ceramic filters are a suitable technology to reduce turbidity, hardness, E.coli, and Total Coliform contained in water. The addition of silver nitrate $\left(\mathrm{AgNO}_{3}\right)$ to ceramic filters must be done to reduce microbiological contamination.

\section{ACKNOWLEDGMENT}

The author thanks the various parties who have helped in this research. This research was funded by the Kalsruhe Institute of Technology Germany.

\section{REFERENCES}

[1] Asmadi, K., dan Kasjono, H.S., (2011), Teknologi pengolahan air minum, Gosyen Publishing, Yogyakarta.

[2] Clasen, T.F., Garcia, P.G., Boisson S., Collin S., (2005), Household-based Ceramic Water Filters for The Prevention of Diarrhea: A Randomized, Controlled Trial of a Pilot Program in Colombia, Am J Trop, Medichine Hygiene, Volume 73(4), Halaman 790-795.

[3] Ekpunobi, U.E., Agbo, S.U., and Ajiwe, V.I.E., (2019), Evaluation Of The Mixtures Of Clay, Diatomite, And Sawdust For Production Of Ceramic Pot Filters For Water Treatment Interventions Using Locally Sourced Materials, Journal of Environmental Chemical Engineering, 7, 102791.

[4] Fewtrell L., Kaufmann R., Kay D., Enanoria W., Haller L., Colford J., (2005). Water, Sanitation, and Hygiene Interventions to Reduce Diarrhea in Less Developed Countries: A Systematic Review and Meta-analysis, Lancet Infect Dis, Volume 5, Halaman 42-52.

[5] Hagan, J.M., Harley, N., Pointing, D., Sampson, M., Smith, K., Soam, V., (2009), Resource Development International - Cambodia Ceramic Water Filter Handbook, Versi 1.1, Phnom Penh, Kamboja.

[6] Hutton, G., and Haller, L., (2004), Evaluation of The Costs and Benefits of Water and Sanitation Improvements at The Global Level, Geveva: World Health Organization (WHO).

[7] Kementerian Kesehatan, (2010), Riset Kesehatan Dasar 2010, Jakarta: Badan Penelitian dan Pengembangan Kesehatan Kementerian Kesehatan.

[8] Kementerian Kesehatan. (2014). Profil Kesehatan Indonesia Tahun 2013. Jakarta : Kementerian Kesehatan

[9] Matthies, K., (2015), Development Of A Ceramic Filtration For Point-Of-Use Drinking Water Treatment In A Tropical Karst Region, Karlsruhe Institute of Technology, Karlsruhe. 
[10] Roger, P.P., llamas, M. Ramon, Martinez-Cortina, Luis, (2004), Water Crisis : Myth or Reality?, Marcelino Botin Water Forum 2004, Halaman 3-4.

[11] Sophie, B., (2008), Silver Impregnated Ceramic Water Filter Flowrate versus The Removal Efficiency of Pathogens, Stevinweg : Delf University of Technology.

[12] Van Der Laan, , H., Van Halem, D., Smeets, P.W., Soppe, A.I., Kroesbergen, J., Wubbels, G., Nederstigt, J., Gensburger, I., Heijman, S.G., (2013). Bacteria And Virus Removal Effectiveness Of Ceramic Pot Filters With Different Silver
Applications In A Long Term Experiment, Water Research 51, 47-54.

[13] Vidal, A.P., Gomez, D.J., Rozo, J.C., Perilla, O.L.U., (2016), Long-Term Evaluation Of The Performance Of Four Point-Of-Use Water Filters, Water Research, 98, 176-182.d

[14] WHO, (2006), Guidelines for drinking-water quality: first addendum to third edition. World Health Organization: Geneva.

[15] WHO, (2013), Household Water Treatment and Safe Storage : Manual for Participant. Geneva : World Health Organization Regional Office for the Western Pacific. 